DOT/FAA/AM-09/12

Office of Aerospace Medicine

Washington, DC 20591

\title{
Increased Cannabinoids Concentrations Found in Specimens From Fatal Aviation Accidents Between 1997 and 2006
}

Dennis V. Canfield

Kurt M. Dubowski

James E. Whinnery

Russell J. Lewis

Roxane M. Ritter

Civil Aerospace Medical Institute

Federal Aviation Administration

Oklahoma City, OK 73125

June 2009

Final Report 


\section{NOTICE}

This document is disseminated under the sponsorship of the U.S. Department of Transportation in the interest of information exchange. The United States Government assumes no liability for the contents thereof.

This publication and all Office of Aerospace Medicine technical reports are available in full-text from the Civil Aerospace Medical Institute's publications Web site: www.faa.gov/library/reports/medical/oamtechreports 
Technical Report Documentation Page

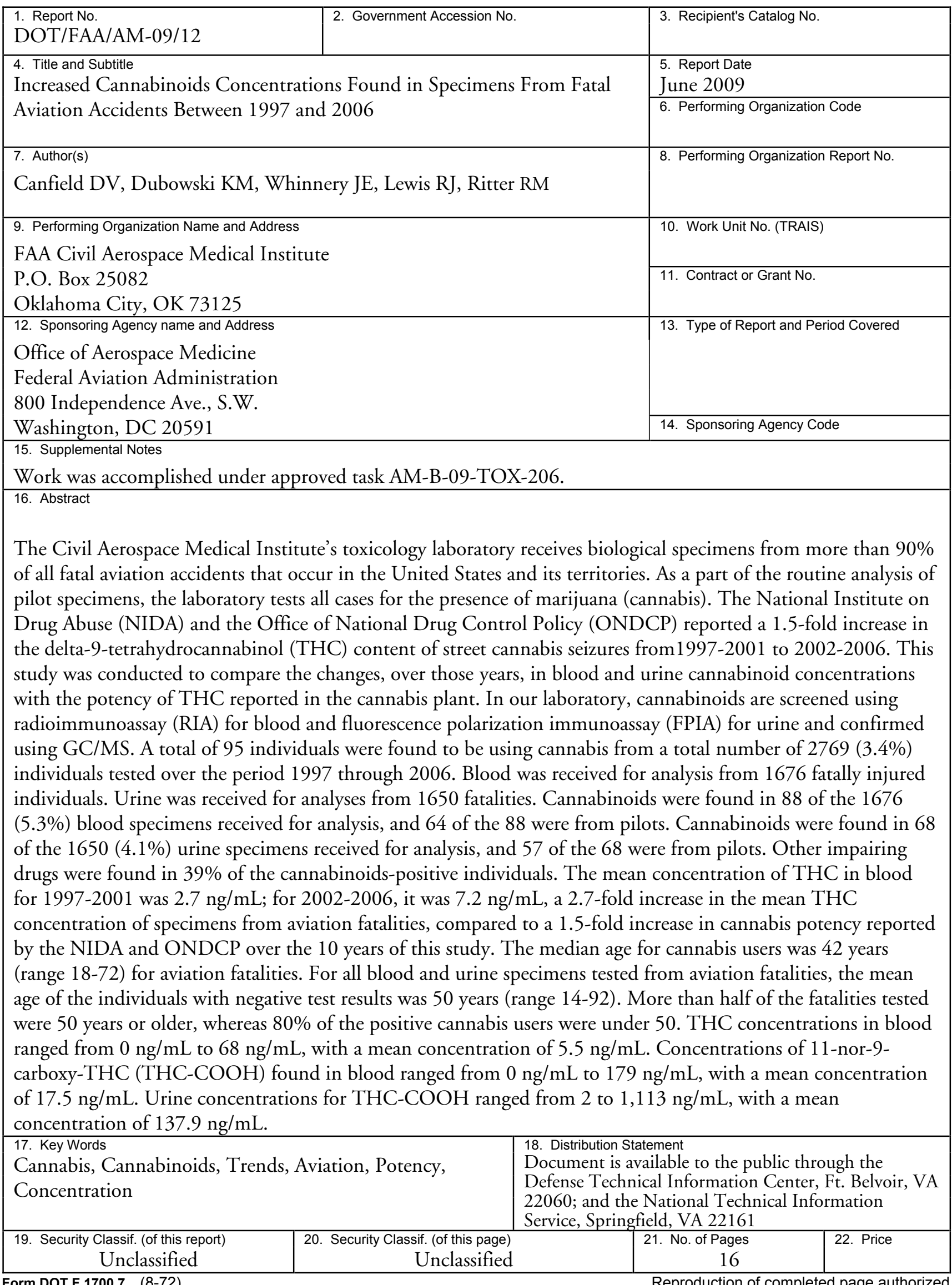

Form DOT F 1700.7 (8-72) Reproduction of completed page authorized 



\section{ACKNOWLEDGMENTS}

We thank the Federal Aviation Administration Office of Aviation Accident Investigation and the Office of Aerospace Medicine for sponsoring this research. 



\section{CONTENTS}

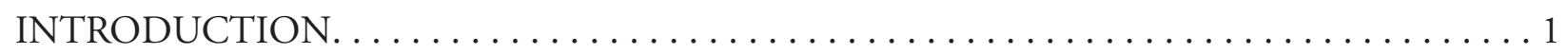

MATERIALS AND METHODS $\ldots \ldots \ldots \ldots \ldots \ldots \ldots \ldots \ldots \ldots \ldots \ldots \ldots \ldots$

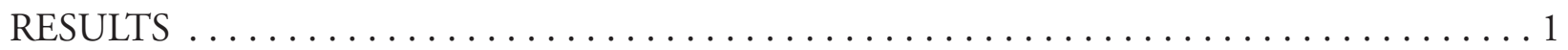

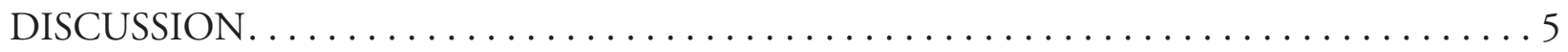

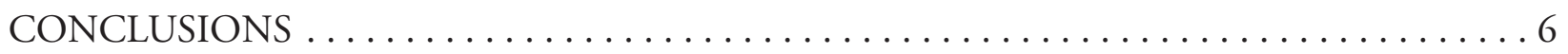

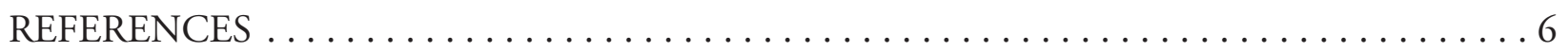





\section{InCreased Cannabinoids Concentrations Found in Specimens From Fatal Aviation Accidents Between 1997 and 2006}

\section{INTRODUCTION}

Although it remains the most commonly used illicit drug in the United States cannabis use has declined slightly over the past 10 years. ${ }^{1,2}$ However, the potency of cannabis, as measured by delta-9-tetrahydrocannabinol (THC) concentrations, has nearly doubled from 1997 to $2006 .^{3}$ This increased potency could result in higher concentrations of THC and incidence of impairment in persons working in the transportation industry. It has also been reported that marijuana use disorders among cannabis users, which are already the most prevalent illicit substance use disorders in the population, increased significantly $(P=0.002)$ between 1991-1992 and 20012002 in the absence of increased frequency and quantity of cannabis use, suggesting that concomitant increased cannabis potency may have contributed to the rising rates of cannabis use disorders. ${ }^{4}$

Recent studies have shown that cannabis users choose to smoke high-potency cannabis more often than lowpotency cannabis. ${ }^{5}$ High-potency cannabis users will generally increase their average THC intake. ${ }^{6}$ There are contradictory reports that subjects do not regulate their cannabis smoke intake in response to changes in cannabis potency ${ }^{7}$ and that they do titrate their intake. ${ }^{8}$ If cannabis users do titrate the amount of cannabis used based on its potency, one would not expect a significant increase in the concentration of cannabinoids found in blood samples collected over a 10 -year period during which the potency of the cannabis significantly increased.

Most of the earlier performance studies used lowpotency cannabis, compared to the potency of cannabis available today, and probably do not reflect the performance impairment potential of high-potency cannabis. ${ }^{9}$ Studies conducted with high-potency cannabis have demonstrated consistent impairment of executive function, tracking performance, and motor impulse control. ${ }^{6}$ The impairment was shown to last for up to 6 hours after smoking. There is other recent evidence that the use of cannabis is not harmless. ${ }^{4,10,11}$

Research has shown that THC concentrations in blood between 3.5-5.0 ng/mL (plasma 7-10 ng/mL) have an impairing effect on drivers equivalent to a blood alcohol concentrations $0.05 \% .{ }^{12}$ The FAA prohibits pilots from operating an aircraft with blood alcohol concentrations at or above $0.04 \%$. That raises the question of how many aviation accidents are found with pilots having blood THC concentrations at or above the impairing range, compared to fatal aviation accidents that occurred prior to the availability of high-potency cannabis.

This study was undertaken to compare the change in reported cannabis potency with changes in the concentrations of THC and its 11-nor-9-carboxy-THC (THC-COOH) metabolite found in urine and blood from fatal aviation accidents during the period from 1997 to 2006.

\section{MATERIALS AND METHODS}

The Civil Aerospace Medical Institute (CAMI) receives biological fluids and tissues for toxicology analysis from all aviation accidents that occur nationwide. Blood specimens received from pilots are screened for THC-COOH by radioimmunoassay (RIA) and urine specimens by fluorescence polarization immunoassay (FPIA). Solid phase extraction is used to isolate THC and THC-COOH from blood and urine. The confirmation and quantitation of THC-COOH in urine is performed using gas chromatography and electron impact mass spectrometry (GC/MS). THC and THC-COOH in blood are confirmed and quantitated by negative-ion chemical ionization GC/MS, based on a modification of a procedure published in $1983 .{ }^{13}$ The procedure used to analyze cannabinoids includes deuterated internal standards and has a limit of detection and a limit of quantitation of 1 $\mathrm{ng} / \mathrm{mL}$ in blood and urine.

A 10-year period from 1997 to 2006 was selected for this study to correlate with data reported by the National Institute on Drug Abuse (NIDA) and the Office of National Drug Control Policy (ONDCP) on cannabis potency. ${ }^{3}$ Cannabinoids concentrations in blood and urine were compared with the reported potency of cannabis during the same time period.

\section{RESULTS}

The principal findings of this study are contained in Tables 1-6. From 1997 through 2006, a total of 95 (3.4\%) individuals where found to have used cannabis of 2769 individuals tested. Of the 95 cannabinoids- 
Table 1. Demographics of the Study Subjects and Number of

Cannabinoids-Positive and Negative Results.

\begin{tabular}{|l|r|r|r|r|r|}
\hline Category & \multicolumn{1}{|c|}{ N } & Age Mean & SD & Age Median & Age Range \\
\hline Males Positive & 87 & 40 & 12 & 42 & $18-72$ \\
\hline Males Negative & 2543 & 50 & 15 & 51 & $14-92$ \\
\hline Total & 2630 & 50 & 15 & 50 & $14-92$ \\
\hline Females Positive & 8 & 36 & 9 & 39 & $24-45$ \\
\hline Females Negative & 120 & 44 & 15 & 44 & $17-77$ \\
\hline Total & 128 & 44 & 15 & 44 & $17-77$ \\
\hline Undesignated Positive & 0 & $\mathrm{NA}$ & $\mathrm{NA}$ & $\mathrm{NA}$ & $\mathrm{NA}$ \\
\hline Undesignated Negative & 11 & 36 & 9 & 39 & $19-44$ \\
\hline Total & 11 & 36 & 9 & 39 & $19-44$ \\
\hline All Total Positive & 95 & 40 & 12 & 42 & $18-72$ \\
\hline All Total Negative & 2674 & 50 & 15 & 51 & $14-92$ \\
\hline All Total & 2769 & 49 & 15 & 50 & $14-92$ \\
\hline
\end{tabular}

Table 2. Cannabinoids-Positive Results in Blood by Year of Study.

\begin{tabular}{|r|c|c|c|c|c|c|c|c|c|}
\hline & \multirow{2}{*}{ Year } & $\mathbf{N}$ & $\mathbf{\Delta} \mathbf{~ T H C}$ & \multicolumn{3}{c}{$\mathbf{n g} / \mathbf{m L}$} & Blood & \multicolumn{1}{c|}{ TCH-COOH } & \multicolumn{3}{c|}{$\mathbf{n g} / \mathbf{m L}$} & Blood \\
\hline & Mean & SD & Median & Span & Mean & SD & Median & Span \\
\hline $\mathbf{1 9 9 7}$ & 9 & 1.3 & 2.6 & 0.0 & $0.0-8.0$ & 11.6 & 13.0 & 9.0 & $1.0-41.0$ \\
\hline $\mathbf{1 9 9 8}$ & 7 & 0.9 & 1.9 & 0.0 & $0.0-5.0$ & 4.7 & 4.2 & 2.0 & $1.0-11.0$ \\
\hline $\mathbf{1 9 9 9}$ & 7 & 3.1 & 4.3 & 2.0 & $0.0-12.0$ & 14.7 & 15.5 & 11.0 & $1.0-42.0$ \\
\hline $\mathbf{2 0 0 0}$ & 8 & 3.9 & 4.7 & 2.0 & $0.0-13.0$ & 9.1 & 16.2 & 2.0 & $1.0-48.0$ \\
\hline $\mathbf{2 0 0 1}$ & 9 & 4.2 & 7.3 & 1.0 & $0.0-19.0$ & 18.1 & 21.1 & 6.0 & $1.0-53.0$ \\
\hline $\mathbf{2 0 0 2}$ & 6 & 1.0 & 2.0 & 0.0 & $0.0-5.0$ & 3.8 & 4.8 & 1.0 & $0.0-11.0$ \\
\hline $\mathbf{2 0 0 3}$ & 19 & 7.8 & 16.3 & 2.0 & $0.0-68.0$ & 11.0 & 7.4 & 12.0 & $1.0-22.0$ \\
\hline $\mathbf{2 0 0 4}$ & 7 & 9.9 & 15.4 & 2.0 & $0.0-37.0$ & 20.9 & 32.5 & 10.0 & $1.0-92.0$ \\
\hline $\mathbf{2 0 0 5}$ & 7 & 2.7 & 2.4 & 2.0 & $0.0-7.0$ & 25.9 & 44.1 & 8.0 & $1.0-122.0$ \\
\hline $\mathbf{2 0 0 6}$ & 9 & 14.8 & 20.5 & 5.0 & $2.0-65.0$ & 56.0 & 67.3 & 28.0 & $8.0-179.0$ \\
\hline Totals & $\mathbf{8 8}$ & $\mathbf{5 . 5}$ & $\mathbf{1 1 . 7}$ & $\mathbf{1 . 5}$ & $\mathbf{0 . 0 - 6 8 . 0}$ & $\mathbf{1 7 . 5}$ & $\mathbf{3 0 . 6}$ & $\mathbf{8 . 5}$ & $\mathbf{0 . 0 - 1 7 9 . 0}$ \\
\hline
\end{tabular}

Table 3. Cannabinoids-Positive Results in Urine by Year of Study.

\begin{tabular}{|c|c|c|c|c|c|}
\hline & & $\mathrm{TCH}-\mathrm{COOH}$ & & $\mathrm{ng} / \mathrm{mL}$ & Urine \\
\hline Year & $\mathbf{N}$ & Mean & SD & Median & Span \\
\hline 1997 & 10 & 98.0 & 211.8 & 26.0 & $2.0-695.0$ \\
\hline 1998 & 6 & 31.5 & 36.6 & 14.0 & $3.0-100.0$ \\
\hline 1999 & 8 & 98.5 & 161.5 & 43.5 & $10.0-493.0$ \\
\hline 2000 & 5 & 68.0 & 57.2 & 37.0 & $18.0-147.0$ \\
\hline 2001 & 6 & 142.0 & 131.1 & 83.0 & $40.0-388.0$ \\
\hline 2002 & 6 & 52.2 & 47.1 & 41.5 & $9.0-142.0$ \\
\hline 2003 & 11 & 113.9 & 178.6 & 29.0 & $3.0-600.0$ \\
\hline 2004 & 3 & 316.7 & 465.1 & 86.0 & $12.0-852.0$ \\
\hline 2005 & 6 & 182.2 & 203.8 & 87.0 & $31.0-543.0$ \\
\hline 2006 & 7 & 373.9 & 382.7 & 308.0 & $8.0-1113.0$ \\
\hline Totals & 68 & 137.9 & 218.9 & 45.5 & $2.0-1113.0$ \\
\hline
\end{tabular}


Table 4. Summary of Results in Urine for Cannabinoids and Other Impairing Drugs by Year of Study.

\begin{tabular}{|c|c|c|c|c|}
\hline Year & $\begin{array}{c}\text { CasesTested } \\
\text { for Cannabinoids }\end{array}$ & $\begin{array}{c}\text { Negative } \\
\text { Cannabinoids }\end{array}$ & $\begin{array}{c}\text { Positive } \\
\text { Cannabinoids }\end{array}$ & $\begin{array}{c}\text { Cannabinoids } \\
\text { \& Other Drugs }\end{array}$ \\
\hline $\mathbf{1 9 9 7}$ & 191 & 181 & 10 & 5 \\
\hline $\mathbf{1 9 9 8}$ & 176 & 170 & 6 & 2 \\
\hline $\mathbf{1 9 9 9}$ & 162 & 154 & 8 & 2 \\
\hline $\mathbf{2 0 0 0}$ & 163 & 158 & 5 & 2 \\
\hline $\mathbf{2 0 0 1}$ & 162 & 156 & 6 & 1 \\
\hline $\mathbf{2 0 0 2}$ & 150 & 144 & 6 & 1 \\
\hline $\mathbf{2 0 0 3}$ & 187 & 176 & 11 & 4 \\
\hline $\mathbf{2 0 0 4}$ & 159 & 156 & 3 & 3 \\
\hline $\mathbf{2 0 0 5}$ & 163 & 157 & 6 & 3 \\
\hline $\mathbf{2 0 0 6}$ & 137 & 130 & 7 & 3 \\
\hline Totals & $\mathbf{1 6 5 0}$ & $\mathbf{1 5 8 2}$ & $\mathbf{6 8}$ & $\mathbf{2 6}$ \\
\hline
\end{tabular}

Table 5. Summary of Results in Blood for Cannabinoids and Other Impairing Drugs by Year of Study.

\begin{tabular}{|c|c|c|c|c|}
\hline Year & $\begin{array}{c}\text { CasesTested } \\
\text { for Cannabinoids }\end{array}$ & $\begin{array}{c}\text { Negative } \\
\text { Cannabinoids }\end{array}$ & $\begin{array}{c}\text { Positive } \\
\text { Cannabinoids }\end{array}$ & $\begin{array}{c}\text { Positive } \\
\text { Cannabinoids } \\
\text { \& Other Drugs }\end{array}$ \\
\hline $\mathbf{1 9 9 7}$ & 178 & 169 & 9 & 5 \\
\hline $\mathbf{1 9 9 8}$ & 140 & 133 & 7 & 2 \\
\hline $\mathbf{1 9 9 9}$ & 165 & 158 & 7 & 2 \\
\hline $\mathbf{2 0 0 0}$ & 163 & 155 & 8 & 3 \\
\hline $\mathbf{2 0 0 1}$ & 157 & 148 & 9 & 1 \\
\hline $\mathbf{2 0 0 2}$ & 168 & 162 & 6 & 1 \\
\hline $\mathbf{2 0 0 3}$ & 197 & 178 & 19 & 9 \\
\hline $\mathbf{2 0 0 4}$ & 179 & 172 & 7 & 5 \\
\hline $\mathbf{2 0 0 5}$ & 167 & 160 & 7 & 2 \\
\hline $\mathbf{2 0 0 6}$ & 162 & 153 & 9 & 5 \\
\hline Totals & $\mathbf{1 6 7 6}$ & $\mathbf{1 5 8 8}$ & $\mathbf{8 8}$ & $\mathbf{3 5}$ \\
\hline
\end{tabular}

Table 6. Ratio of Blood to Urine Cannabinoids.

\begin{tabular}{|l|r|r|r|l|r|r|}
\hline $\begin{array}{l}\text { Urine-Range } \\
\text { ng/mL }\end{array}$ & $\begin{array}{l}\text { Mean Blood } \\
\text { THC }\end{array}$ & $\begin{array}{l}\text { Mean Blood } \\
\text { THC-COOH }\end{array}$ & $\begin{array}{l}\text { Mean Urine } \\
\text { THC-COOH }\end{array}$ & $\begin{array}{l}\text { Blood/Urine } \\
\text { THC-COOH }\end{array}$ & $\begin{array}{l}\text { Blood THC } \\
\text { Irine } \\
\text { THC-COOH }\end{array}$ & $\mathbf{N}$ \\
\hline $0-9.0$ & 0.8 & 3.5 & 4.9 & 1 & 6 & 8 \\
\hline $10-14.0$ & 5 & 4 & 12.1 & 3 & 2 & 8 \\
\hline Mean & $\mathbf{2 . 9}$ & $\mathbf{3 . 8}$ & $\mathbf{8 . 5}$ & $\mathbf{2}$ & $\mathbf{4}$ & $\mathbf{8}$ \\
\hline SD & $\mathbf{3 . 0}$ & $\mathbf{0 . 4}$ & $\mathbf{5 . 1}$ & $\mathbf{1 . 4}$ & $\mathbf{2 . 8}$ & $\mathbf{0}$ \\
\hline $15.0-30.0$ & 1.9 & 1.9 & 21.8 & 11 & 11 & 8 \\
\hline $31.0-60.0$ & 1 & 6.4 & 40.5 & 6 & 41 & 12 \\
\hline $61.0-100.0$ & 1.1 & 10.6 & 82.2 & 8 & 75 & 13 \\
\hline $100.0-400.0$ & 3.4 & 17.4 & 201.1 & 12 & 59 & 11 \\
\hline $400.0-1113.0$ & 13 & 55.4 & 662.3 & 12 & 51 & 8 \\
\hline Mean & $\mathbf{4 . 1}$ & $\mathbf{1 8 . 3}$ & $\mathbf{2 0 1 . 6}$ & $\mathbf{9 . 8}$ & $\mathbf{4 7 . 4}$ & $\mathbf{1 0}$ \\
\hline SD & $\mathbf{5 . 1}$ & $\mathbf{2 1 . 5}$ & $\mathbf{2 6 6 . 8}$ & $\mathbf{2 . 7}$ & $\mathbf{2 3 . 8}$ & $\mathbf{2 . 3}$ \\
\hline
\end{tabular}


positive individuals, 39\% were also found positive for other impairing drugs. Blood was received for analysis from 1676 fatalities. Urine was received for analysis from 1650 fatally injured individuals. Cannabinoids were found in $88(5.3 \%)$ of the 1676 blood specimens received for analysis, and 64 of these were from pilots. Cannabinoids were found in $68(4.1 \%)$ of the 1650 urine specimens received for analysis; 57 of these were from pilots.

The median age for cannabis users was 42 years among the fatally injured aviation individuals, with a range from 18 to 72 (Figure 1). For negative cannabinoids in blood and urine specimens tested, the median age was 50 years, with a span from 14 to 92 . More than half of the fatally injured persons tested were 50 years or older, whereas $80 \%$ of the cannabis users were under 50 .

THC concentrations in blood ranged from 0 to $68 \mathrm{ng} / \mathrm{mL}$, with a mean of $5.5 \mathrm{ng} / \mathrm{mL}$. THC-COOH concentrations in blood ranged from 0 to $179 \mathrm{ng} / \mathrm{mL}$, with a mean of $17.5 \mathrm{ng} / \mathrm{mL}$. Urine concentrations of THC-COOH ranged from 2 to $1,113 \mathrm{ng} / \mathrm{mL}$, with a mean of $137.9 \mathrm{ng} / \mathrm{mL}$.

Between 1997 and 2001, 8 positive THC cases of 55 positive cannabinoids cases in blood were at or above 3.5 $\mathrm{ng} / \mathrm{mL}$, while 20 of the reported 51 positive cannabis cases in blood from 2002 to 2006 were at or above 3.5 $\mathrm{ng} / \mathrm{mL}$. This is more than a two-fold increase over those years with lower cannabis potency.

The data indicated an approximately $1 / 10 \mathrm{blood} / \mathrm{urine}$ THC-COOH ratio for urine THC-COOH concentrations above $15 \mathrm{ng} / \mathrm{mL}$. For urine THC-COOH concentrations at or below $15 \mathrm{ng} / \mathrm{mL}$, there was an approximately $1 / 2 \mathrm{blood} /$ urine THC-COOH ratio. The ratio of the mean blood THC concentration to the mean urine THC-COOH concentration for urine specimens with
THC-COOH concentrations at or below $15 \mathrm{ng} / \mathrm{mL}$ was $1 / 3$ and $1 / 50$ for concentrations above $15 \mathrm{ng} / \mathrm{mL}$.

The mean concentration of THC in blood for the period 1997-2001 was $2.7 \mathrm{ng} / \mathrm{mL}$ it was $7.2 \mathrm{ng} / \mathrm{mL}$ for 2002-2006, a 2.7-fold increase in the mean THC concentration of specimens from aviation fatalities. The annual mean THC concentration found in blood increased from $1.3 \mathrm{ng} / \mathrm{mL}$ in 1997 to $14.8 \mathrm{ng} / \mathrm{mL}$ in 2006, an 11.3-fold increase. The annual maximum THC concentration found in blood increased from $8 \mathrm{ng} / \mathrm{mL}$ in 1997 to 65 $\mathrm{ng} / \mathrm{mL}$ in 2006 , an 8.1 -fold increase.

The mean concentration of THC-COOH in blood for the period 1997-2001 was $11.6 \mathrm{ng} / \mathrm{mL}$, and for 20022006 it was $23.5 \mathrm{ng} / \mathrm{mL}$, a 2.0 -fold increase in the mean $\mathrm{THC}-\mathrm{COOH}$ concentration of specimens from aviation fatalities. The annual mean THC-COOH concentration found in blood increased from $11.6 \mathrm{ng} / \mathrm{mL}$ in 1997 to $56.0 \mathrm{ng} / \mathrm{mL}$ in 2006 , a 4.8 -fold increase. The annual maximum THC-COOH concentration found in blood increased from $41 \mathrm{ng} / \mathrm{mL}$ in 1997 to $179 \mathrm{ng} / \mathrm{mL}$ in 2006, a 4.4-fold increase.

Urine specimens were received from 740 fatally injured pilots designated as airline transport or commercial pilots, and $14(1.9 \%)$ of the commercial pilot cases exceeded the DOT workplace drug testing urine THC-COOH confirmation threshold $(15 \mathrm{ng} / \mathrm{mL}){ }^{14}$

No cannabinoids were found in specimens from the airline transport pilots tested. Eight (57\%) fatally injured commercial pilots (including agricultural pilots) found with a urine THC-COOH in excess of the DOT workplace drug testing urine threshold were flying private planes. Urine specimens from fatally injured agricultural pilots (Part 137) were found to exceed the DOT workplace drug testing threshold THC-COOH in $5(36 \%)$

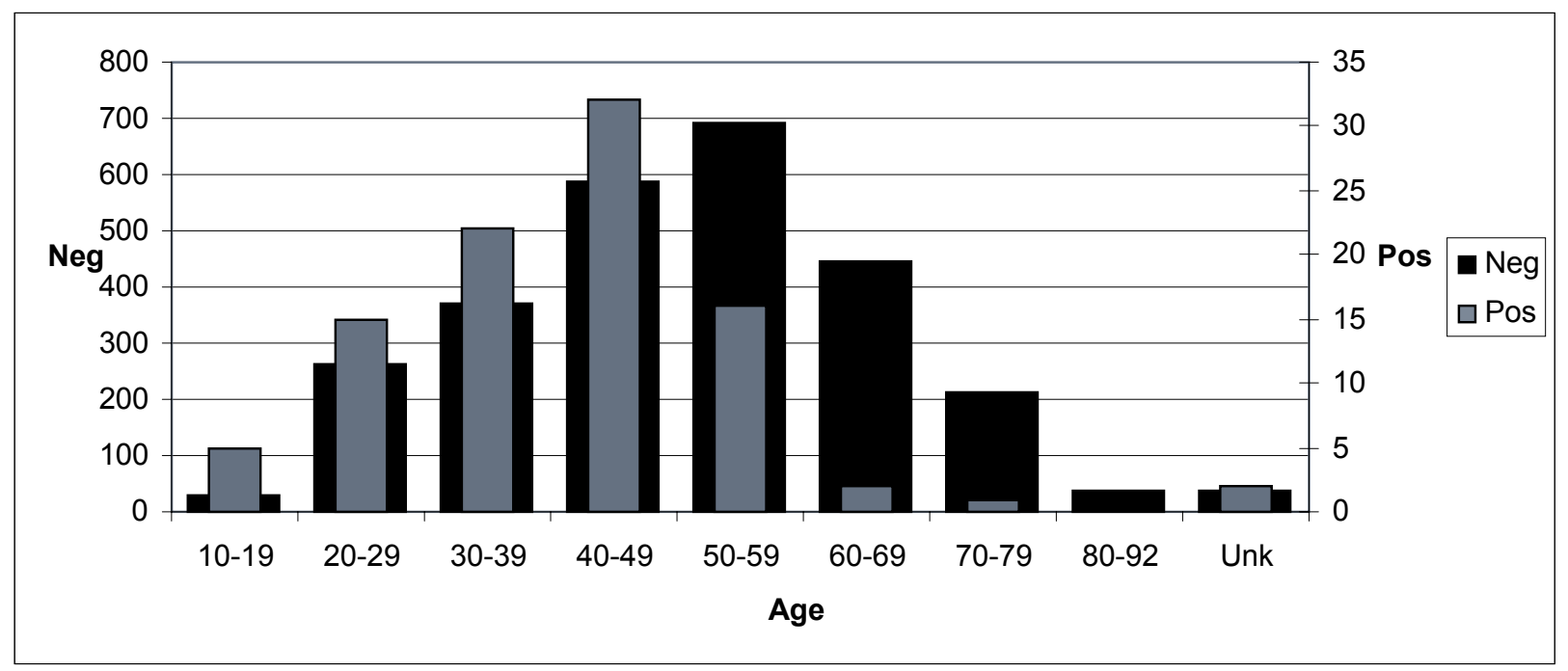

Figure 1. Graphic display of age distribution for all fatal pilots and cannabis users. 
of the THC-COOH positive cases. One fatally injured commercial air taxi pilot (Part 135) was found to exceed the DOT workplace drug testing urine threshold for THC-COOH.

In the present study, 61 of 2,769 cases $(2.2 \%)$ were found to have ethanol at or above $40 \mathrm{mg} / \mathrm{dL}(0.04 \%)$ in blood or urine.

\section{DISCUSSION}

The 2.7-fold increase in the mean blood THC concentration found in this study for the 1997-2001 and 2002-2006 periods compares to a 1.5 -fold increase in the mean THC concentration of cannabis reported by the National Drug Intelligence Center (NDIC) for the 1997-2001 and 2002-2006 periods. The reasons for this difference are presently unknown. The analytical toxicology procedures for $\mathrm{THC}$ and $\mathrm{THC}-\mathrm{COOH}$ used at CAMI remained the same during the period of this study, as did the quality assurance and quality control procedures, including internal and external "blind" performance testing.

In 2006, $0.05 \%$ of the individuals (flight crewmembers) tested in the FAA aviation industry random drug testing program were found to be positive for marijuana: ${ }^{15}$ $6.0 \%$ of the commercial pilots tested in the CAMI forensic drug testing laboratory (fatal aviation accident pilots) were positive for THC-COOH at or above the threshold of 15 $\mathrm{ng} / \mathrm{mL}$ THC-COOH in urine. The commercial pilots tested in the CAMI forensic toxicology department for 2006 were flying private planes (Part 91) or crop dusters (Part 137). Not all commercial pilots (agricultural pilots, for example) are required to participate in the random drug testing program.

Government agencies and the scientific literature repeatedly reported that the potency of cannabis has been increasing over the 10 years of this study. $3,16,17$ The mean concentration of THC in blood specimens from fatal aviation accidents tested by CAMI has also increased over the last 10 years, but at a greater rate than marijuana potency (Figure 2). Research conducted in Sweden also found an increase in the mean concentration of THC in blood from 1.8 to $2.3 \mathrm{ng} / \mathrm{mL}$ in a 10 -year (1995-2004) study of drug impaired drivers. ${ }^{18}$

Controlled laboratory experiments on driving-related skills reported in the literature have shown that THC concentrations between 2 and $5 \mathrm{ng} / \mathrm{mL}$ in whole blood are associated with driver impairment. ${ }^{19}$ Serum THC concentrations between 7-10 ng/mL (whole blood, approximately $3.5-5.0 \mathrm{ng} / \mathrm{mL}$ ) have been compared to a blood alcohol concentration of $0.05 \%,{ }^{12}$ which exceeds the DOT alcohol threshold of $0.04 \%$ (BAC) for transportation workers in safety-sensitive positions. It is clear that the use of high-potency cannabis could significantly alter the performance of an individual, assuming the blood THC concentrations increase correspondingly.

In a study in Norway, $589(2.0 \%)$ samples of approximately 30,000 samples from impaired drivers were found to contain only THC as the impairing drug. ${ }^{20}$ The Norway epidemiological study indicated an association of driving impairment in individuals at or above $2.5 \mathrm{ng} /$ $\mathrm{mL}$ THC in blood and found no impairment at blood THC concentrations at or below $1.9 \mathrm{ng} / \mathrm{mL}$ in suspected drugged drivers. ${ }^{20}$ This is consistent with earlier findings

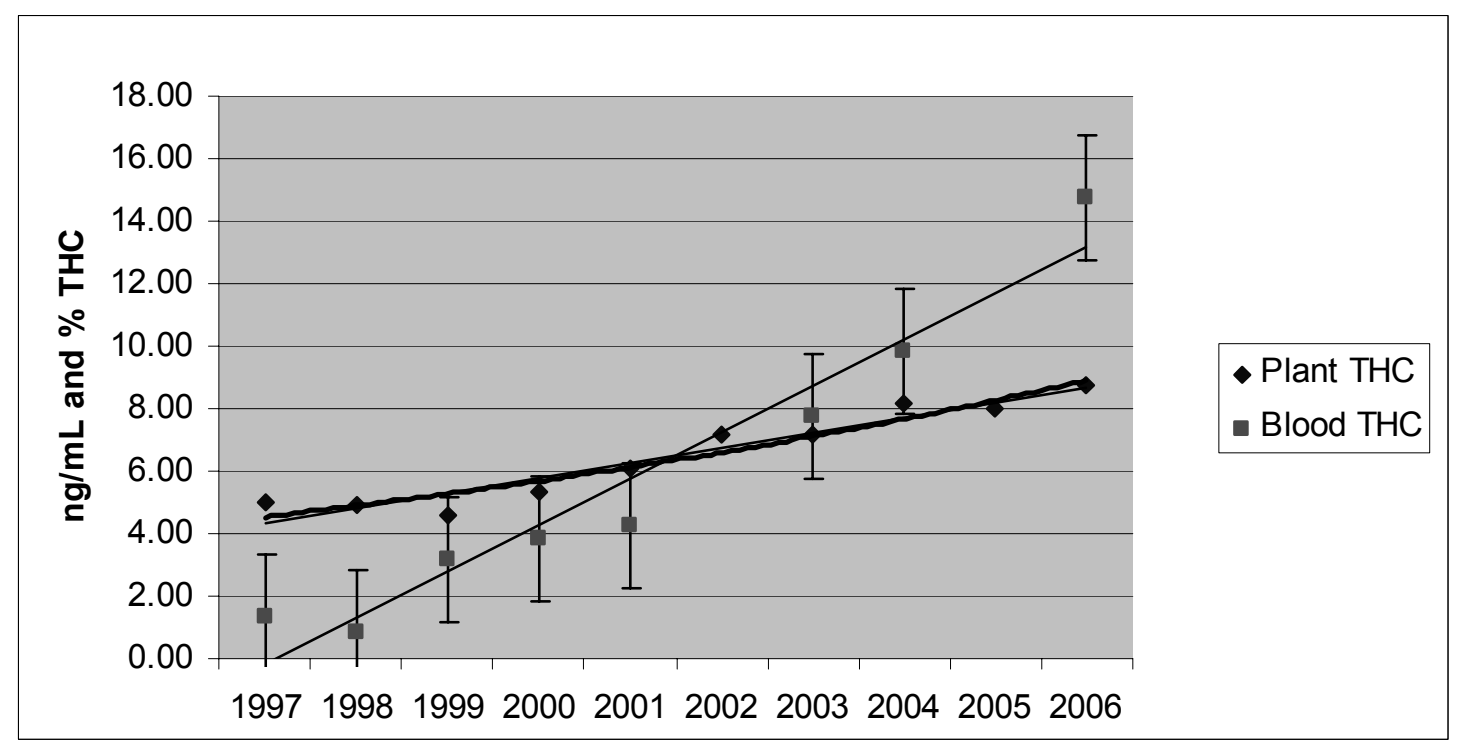

Note: Blood THC results for 2002 and 2005 were removed as outliers from this graph.

Figure 2. Increase in blood THC (ng/mL) and cannabis potency (\% THC) 1997-2006. 
of a linear, dose-related, physiological response to THC. ${ }^{21}$ "Furthermore, drivers with blood THC concentrations above $3 \mathrm{ng} / \mathrm{mL}$ had an increased risk for being judged impaired compared to drivers with lower concentration ranges . "20 In our research, we found that approximately $46 \%(22 / 48)$ of the blood samples positive for THC from 2002-2006 had concentrations of THC greater than $3.5 \mathrm{ng} / \mathrm{mL}$, whereas only $25 \%(10 / 40)$ exceeded that concentration between 1997 and 2001.

Although there were only 95 cannabinoids-positive cases reported in this study, cannabis use may be more prevalent in the driving population and in other modes of transportation. A 10-year study from 1995 to 2004 of drug impaired drivers in Sweden found that 8,794 drivers had THC in their blood; ${ }^{18}$ constituting a proportion rising from 18 to $29 \%$ of all tested specimens during that decade. This suggests that the prevalence of THC in the driving population is far higher than we found in aviation fatalities.

A study of 1,079 commercial tractor-trailer drivers in the State of Washington found that $4.3 \%$ of the drivers were using cannabis, while $1.3 \%$ of the drivers were using alcohol; ${ }^{22}$ cannabis use in truck drivers was 3.3 times as prevalent as alcohol use in this 2002 report. $^{22}$ In our study of aviation fatalities cannabis use was found to be 1.7 times greater than alcohol use at or above 40 $\mathrm{mg} / \mathrm{dL}$ in blood or urine. These findings are contrary to the widely held perception that alcohol is the most commonly abused drug in transportation. It is also important to recognize that some of the alcohol positive cases found in aviation fatalities in this study could have been the result of postmortem ethanol formation. ${ }^{23}$

Cannabis use in conjunction with other impairing substances such as alcohol has been reported to significantly increase the driving impairment of an individual and to cause impairment by cannabis at much lower concentrations than $3.5 \mathrm{ng} / \mathrm{mL}$ of THC in whole blood. ${ }^{24}$ This study found that $39 \%$ of the positive cannabinoids cases were also positive for other impairing substances.

In a study of THC positive drivers in Sweden, the mean age was reported as 33 years, with a range of 15-66 years. ${ }^{18}$ In our study, the mean age for cannabis users was 40 years for aviation fatalities, with an age range of 18 72. For all blood and urine specimens tested at CAMI, the mean age was 50 years with a range of 14-92. More than half of all fatally injured individuals tested were 50 years, or older; however, $80 \%$ of the cannabinoids users were under 50. It appears from these data that younger individuals were more likely to be using cannabis in aviation, just as in the general population. The driving population is younger than the flying population, and would be more likely to use cannabis and be subject to impairment from the effects of high-potency cannabis. The percentage of cannabis users in motor vehicle accidents could be greater than that found in fatal aviation accidents because of the age differences between drivers and pilots, among other factors.

\section{CONCLUSIONS}

Members of the transportation industry, government regulators, and the general public should be informed of the increased potential for impairment from the use of high potency cannabis currently available and being used.

Further research should be conducted in other modes of transportation to determine the full extent of this trend and its overall impact on transportation accidents.

The typical distribution of THC-COOH in blood/ urine for urine concentrations of THC-COOH above 15 $\mathrm{ng} / \mathrm{mL}$ is approximately $1 / 10$. For THC-COOH urine concentrations at or below $15 \mathrm{ng} / \mathrm{mL}$, the blood/urine distribution was approximately $1 / 2$.

From the data in this study, the number of potentially THC-impaired individuals involved in fatal aviation accidents increased 1.8 times from 1997 to 2006, reflecting the increased number of individuals with concentrations above the reported impairing concentration of THC in blood. Together with the other literature reports cited, this suggests that enhanced counter-measures may be warranted to reduce the use of cannabis by persons involved in transportation.

\section{REFERENCES}

1. Results from the 2006 National Survey on Drug Use and Health: National Findings. In: SAMHSA, Rockville, MD: Office of Applied Studies; 2007:16-25.

2. Marijuana: The greatest cause of illegal drug abuse. In: ONDCP, ed. Marijuana Sourcebook. Vol 2008:2-3.

3. National Drug Control Strategy. Data supplement 2008. In: ONDCP, ed: Executive Office of the President; 2008:66.

4. Compton WM, Grant BF, Colliver JD, Glantz MD, Stinson FS. Prevalence of marijuana use disorders in the United States: 1991-1992 and 2001-2002. Journal of the American Medical Association. May 5 2004;291(17):2114-21.

5. Chait LD, Burke KA. Preference for high- versus low-potency marijuana. Pharmacology, Biochemistry, and Behavior. Nov 1994;49(3):643-7. 
6. Ramaekers JG, Kauert G, van Ruitenbeek P, Theunissen EL, Schneider E, Moeller MR. Highpotency marijuana impairs executive function and inhibitory motor control. Neuropsychopharmacology. Oct 2006;31(10):2296-2303.

7. Chait LD. Delta-9-tetrahydrocannabinol content and human marijuana self-administration. Psychopharmacology. 1989;98(1):51-5.

8. Reinarman C. Cannabis policies and user practices: Market separation, price, potency, and accessibility in Amsterdam and San Francisco. The International Journal on Drug Policy. Mar 24 2008:1-10.

9. Ashton CH. Pharmacology and effects of cannabis: a brief review. British Journal of Psychiatry. Feb 2001;178:101-6.

10. Solowij N, Stephens RS, Roffman RA, et al. Cognitive functioning of long-term heavy cannabis users seeking treatment. Journal of the American Medical Association. Mar 6 2002;287(9):1123-31.

11. Teen marijuana use worsens depression: An analysis of recent data shows "self medication" could actually make things worse. In: ONDCP, ed: Executive Office of the President; 2008:1-7.

12. Grotenhermen F, Leson G, Berghaus G, et al. Developing limits for driving under cannabis. Addiction (Abingdon, England). December 2007;102(12):1910-7.

13. Foltz RL, McGinnis KM, Chinn DM. Quantitative measurement of delta 9-tetrahydrocannabinol and two major metabolites in physiological specimens using capillary column gas chromatography negative ion chemical ionization mass spectrometry. Biomedical Mass Spectrometry. May 1983;10(5):31623.

14. What are the cutoff concentrations for initial and confirmation tests. In: DOT, 49CFR40.87. 10-107 ed.: U.S. Federal Government; 2007:564.

15. Random drug and alcohol testing percentage rates of covered aviation employees for the period of January 1, 2008 through December 31, 2008. In: DOT, 72. Federal Register; 2007:67994.
16. ElSohly MA, Ross SA, Mehmedic Z, Arafat R, Yi B, Banahan BF, 3rd. Potency trends of delta9-THC and other cannabinoids in confiscated marijuana from 1980-1997. Journal of Forensic Sciences. Jan 2000;45(1):24-30.

17. Potter DJ, Clark P, Brown MB. Potency of Del$\mathrm{ta}(9)-\mathrm{THC}$ and other cannabinoids in cannabis in England in 2005: Implications for psychoactivity and pharmacology. Journal of Forensic Sciences. Jan 2008;53(1):90-4.

18. Jones AW, Holmgren A, Kugelberg FC. Driving under the influence of cannabis: A 10-year study of age and gender differences in the concentrations of tetrahydrocannabinol in blood. Addiction (Abingdon, England). Mar 2008;103(3):452-61.

19. Ramaekers JG, Moeller MR, van Ruitenbeek P, Theunissen EL, Schneider E, Kauert G. Cognition and motor control as a function of Delta 9-THC concentration in serum and oral fluid: Limits of impairment. Drug and Alcohol Dependence. Nov 8 2006;85(2):114-22.

20. Khiabani HZ, Bramness JG, Bjorneboe A, Morland J. Relationship between THC concentration in blood and impairment in apprehended drivers. Traffic Injury Prevention. Jun 2006;7(2):111-6.

21. Schaefer CF, Gunn CG, Dubowski KM. Doserelated heart-rate, perceptual, and decisional changes in man following marihuana smoking. Perceptual and Motor Skills. Feb 1977;44(1):3-16.

22. Couper FJ, Pemberton M, Jarvis A, Hughes M, Logan BK. Prevalence of drug use in commercial tractor-trailer drivers. Journal of Forensic Sciences. May 2002;47(3):562-7.

23. Canfield DV, Kupiec T, Huffine E. Postmortem alcohol production in fatal aircraft accidents. Journal of Forensic Sciences. Jul 1993;38(4):914-7.

24. Ramaekers JG, Berghaus G, van Laar M, Drummer $\mathrm{OH}$. Dose related risk of motor vehicle crashes after cannabis use. Drug and Alcohol Dependence. Feb 7 2004;73(2):109-19. 
